\title{
The Views of Prospective Teachers about School Experience Course in the Department of Science Education and Other Departments
}

\author{
Ibrahim Yuksel $^{1} \&$ Hatice Kircicek ${ }^{2}$ \\ ${ }^{1}$ Gazi Faculty of Education, Gazi University, Ankara, Turkey \\ ${ }^{2}$ Institute of Educational Sciences, Gazi University, Ankara, Turkey \\ Correspondence: Ibrahim Yuksel, Gazi Faculty of Education, Gazi University, Ankara, Turkey. E-mail: \\ ibrahimyuksel7@hotmail.com
}

Received: January 30, 2019

Accepted: February 21, 2019

Online Published: February 22, 2019

doi:10.5430/ijhe.v8n1p160

URL: https://doi.org/10.5430/ijhe.v8n1p160

\begin{abstract}
The aim of this study is to determine the views of the prospective teachers in the Department of Science Education and Other Departments about the removal of the School Experience course for the new students who are newly accepted in the undergraduate programs which are updated by the Higher Education Council (HEC) in the 2018-2019 academic year and how the course reflects the teaching profession. The research was carried out with a total of 122 prospective teachers who were selected from the volunteers of the fourth year students of Mathematics and Science Education and Basic Education Departments at the education faculty of a public university in Turkey in the fall semester of 20182019 academic year. In the study, the homogeneous sampling selection was chosen because there were prospective teachers with similar characteristics chosen from the universe and going to the same application school. Interview questions developed by the researchers are used as the main data collection tool and content analysis was done. In the study, the answers obtained from the interview form were themed and interpretations were made based on the results. Most of prospective teachers stated that the School Experience course is useful to the profession and is a necessary to gain experience so it shouldn't be removed. They also mentioned that they gained important experiences for the teaching profession such as classroom management knowledge, method and technique usage knowledge, student teacher relationship, practice, school recognition, teacher observation.
\end{abstract}

Keywords: school experience, prospective teachers, teaching profession

\section{Introduction}

Today, there is a harmony between the educational levels of the countries and the level of development. In order to develop countries, the education of individuals within its structure is important. Well-educated generations, as qualified individuals, follow scientific and technological developments and contribute to the development of the country. The economic, cultural and social development of the society living in a country is related to following the new formations in the developing education system and adaptation to these formations. (Katranci, 2008).

One of the most important elements of the education system is the teachers. Teachers form the building block of the education system. The success of an education system depends on the qualifications of the teachers in that system (Yetim and Goktas, 2004). Teachers who do not possess these qualifications cannot be expected to build an effective and strong future. In order to ensure that individuals receive good education in our country, firstly, qualified teachers should be trained (Saratli, 2007). The main function of the faculties of education in our country is to prepare students with different interests and pre-knowledge to the teaching profession in the most appropriate way. Programs prepared for this purpose are expected to train teachers in similar characteristics and qualifications (Aylar and Aksin, 2011).

The School Experience course in the education programs of our faculties of education is important both in terms of quality and functionality. The School Experience course is a successful way in which prospective teachers are followed for no more than two years to avoid negativity within the classroom. (Kocaturk, 2006). The School Experience course provides to prospective teachers not only professional qualifications but also the knowledge of order and functioning in the future task place. (Ceylan and Akkus, 2007). At the same time, it offers the prospective teachers the opportunity to live their feelings and thoughts, attitudes and habits related to the teaching profession in a real classroom environment. The important thing here is the effective and efficient processing of the course. In order 
to achieve the objectives of the course, it should be conducted in accordance with the content for 5 hours per week as 1 hour of theoretical and 4 hours of practice (Kahyaoglu and Yangin, 2007). $n$ line with the purpose of the School Experience course, prospective teachers have the opportunity to follow the experienced teachers in the schools of the Ministry of National Education (MONE) and benefit from the experiences of the teachers. Sometimes they take the teachers's place and have the opportunity to take care of the students themselves. Thus, it is ensured that pre-service teachers adapt themselves to the real class environment before they start their profession. In 1998, the School Experience course was put into the teacher training program with the 2493 numbered directive on the teaching practice of the prospective teachers in the educational institutions affiliated to the MONE. The matter of how the teachers should be trained which is one of the basic elements of education, as in all societies, is among the mostly emphasized educational issues in Turkey. Various models have been put forward so far about teacher training, and it is still one of the problems that is still important today that the teacher should meet the new needs of societies that are constantly renewing themselves. (Akgul, 2006).

Saritas (2007) states that, as a result of observations of prospective teachers in the School Experience course, their feelings and thoughts about teaching profession are affected. The School Experience course is one of the most important steps in recognizing and understanding the teaching profession and contributes to the professional development of prospective teachers if planned well. The views of prospective teachers about the suitability of the course may make the course content even more efficient. For this reason, it is important to determine the views of prospective teachers in Science Education and other Departments about the removal of the School Experience course for the new students in the undergraduate programs that are updated by the Higher Education Council (HEC) in the 2018-2019 academic year and how the course reflects the teaching profession.

\subsection{Problem Statement}

The general problem statement of this study can be expressed as "What are the views of the prospective teachers in the Science Education Department and other departments about the School Experience course?"

In the selection of the problem, the problem statement and sub-problems were determined by paying attention to the general and specific criteria to be considered. Selected problem statement is thought to be important because it raised awareness in prospective teachers about the School Experience course.

The sub-problems of the study can be listed as follows:

1. How do the prospective teachers assess the removal of the School Experience course for students who are newly enrolled in the undergraduate programs updated by HEC in the 2018-2019 academic year?

2. How does the School Experience course reflect the teaching profession and at which level the School Experience course is useful according to prospective teachers?

3. What does the education received in the schools that are going through within the scope of the School Experience course earn prospective teachers' professional life?

4. Does the experience that prospective teachers gain in the School Experience course contribute to their values education (justice, friendship, honesty, self-control, patience, respect, love, responsibility, patriotism and helpfulness)?

5. Do they think the application teacher they observed in the School Experience class is a professional teacher model for them?

6. Does the School Experience course improve prospective teachers' professional communication skills?

\subsection{Purpose of the Research}

The aim of this study is to determine the views of the prospective teachers in the Department of Science Education and Other Departments about the removal of the School Experience course for the new students who are newly accepted in the undergraduate programs which are updated by the Higher Education Council (HEC) in the 2018-2019 academic year and how the course reflects the teaching profession.

\section{Method}

\subsection{Research Model}

Practices in the School Experience course are mostly under the control of prospective teachers and cannot be influenced from the outside. Therefore, it can be seen from the point of view of the method of the study that there is a structure that is compatible with the relative view. According to the relative approach, research can be done quantitatively and qualitatively (Cepni, 2010). In this research, a case study pattern was used from qualitative 
research designs. The case study is a multidimensional, systematic and in-depth research method that determines a phenomenon within the natural real-life framework where it is found. (Yildirim \& Simsek, 2013). In the case study, it is very important to present the data as detailed as possible, directly and supported by the statements of the participants. (Ekiz, 2003). The case study allows for a quick and in-depth examination of a problem. It allows the researcher to concentrate on a subject or situation. It also offers the researcher the opportunity to explain the situation in terms of cause and effect relationships (Cepni, 2010). In this study, the views of the prospective teachers in the Department of Science Education and Other Departments about the removal of the School Experience course for the new students who are newly accepted in the undergraduate programs which are updated by HEC in the 2018-2019 academic year and how the course reflects the teaching profession were analyzed in detail.

Interview form developed by researchers was used as data collection tool and content analysis was performed. In the study, the answers obtained from the interview form were handled in themes and interpretations were made based on the results.

\subsection{Study Group}

The research was carried out with a total of 122 prospective teachers who were selected from the volunteers of the fourth year students of Mathematics and Science Education and Basic Education Departments at the education faculty of a public university in the fall semester of 2018- 2019 academic year. This sampling method is to study with a similar subgroup of the problem of research from the universe (Buyukozturk, Cakmak, Akgun, Karadeniz, \& Demirel, 2014). In the study, the homogeneous sampling selection was chosen because there were prospective teachers with similar characteristics chosen from the universe and going to the same application school. The prospective teachers in the study were coded as PT1, PT2, PT3.......PT121 and PT122. In addition, demographic data of the prospective teachers according to the departments and gender are given in Table 1 and Table 2.

Table 1. Demographic Data of Gender

\begin{tabular}{lll}
\hline Gender & $\mathrm{f}$ & $\%$ \\
\hline Man & 20 & 16,4 \\
Woman & 102 & 83,6
\end{tabular}

Table 2. Demographic Data of the Department

\begin{tabular}{lll}
\hline Department & $\mathrm{f}$ & $\%$ \\
\hline Department of Science Education & 30 & 24,6 \\
Department of Mathematics Education & 30 & 24,6 \\
Department of Pre-School Education & 19 & 15,6 \\
Department of Biology Education & 17 & 13,9 \\
Department of Chemistry Education & 16 & 13,1 \\
Department of Physics Education & 6 & 4,9 \\
Department of Classroom Teaching & 4 & 3,3 \\
\hline
\end{tabular}

\subsection{Data Collection Tool}

In the case study, interview questions developed by the researchers are used as the main data collection tool. Research data were obtained with analyzing the studies on the subject in Turkey with literature scanning and interview questions developed by the researcher based on the opinions of 6 experts in the field. In order to prepare the interview questions of the study, literature review was done and the researches about the subject were examined. In order to reach the goals determined in this research, interview questions developed for the prospective teachers by the researcher were used as data collection tools. Interview questions are often posed in the form of conversation or in writing. Interview can be expressed as data collection from the sample with the questions asked in the research. In addition, the interview provides in-depth information about a specific research topic or a question to the researcher (Buyukozturk et al., 2014). In this study, semi-structured interview method which is one of the qualitative data collection tools was used in order to reveal the thoughts of teachers. The semi-structured interview method offers an in-depth question on a specific topic, an opportunity to repeat the questions in unfamiliar situations to make the questions more descriptive and to complete the answers. (Cepni, 2010). Browsing related literature, interview questions were developed for a 6-item written interview for prospective teachers who had taken the School Experience course. The questions in the interview form were developed in line with 6 expert opinions and the scope 
validity was ensured. Each interview lasted for 15-25 minutes. During the interviews, the opinions of the prospective teachers were written on the interview form paper with permission.

\subsection{Data Analysis}

Content analysis was performed in data analysis. Content analysis is a method usually used in the analysis of written and visual data. This method is followed by a deductive path. In the content analysis, the researcher first develops categories related to the research topic. Then he counts words, sentences or pictures that fall into these categories. In the category development phase, it should be noted that appropriate categories should be developed that other researchers who plan to carry out a similar research on the same text can reach the results. (Ozdemir, 2010). The main purpose of content analysis is to reach the concepts and relations that can explain the collected data. According to this, it is necessary firstly to conceptualize the collected data and then to organize these concepts in a logical manner and determine the themes that explain the data accordingly. Thus, it is aimed to define the data obtained by content analysis and to reveal the realities hidden within the data (Yildirim and Simsek, 2013).

While analyzing the data in the study, the following steps were followed: Interview questions in the data obtained were converted into text on the computer without any changes by the two experts. Afterwards, the manuscripts were examined one by one and it was seen that there was no inconsistency. In accordance with the statements of the participants, appropriate codes have been established for the purpose of the study. It was checked whether the codes generated by the participants' expressions were suitable for the theme to be emphasized and those that were not suitable were arranged. The statements of the participants were transferred as they were. The participants' statements were grouped separately (same and different views) according to the research questions in accordance with the purpose of the research. In the studies conducted with the case study, how the validity and reliability of the research reports were provided should be explained. Therefore, in the case studies, diversification path can be followed to ensure validity and reliability. Variation is generally thought of as a process of using multiple perceptions to confirm the repetition of an observation or interpretation and to clarify the meaning. But no observations or comments are likewise repeatable one to one. For this reason, comparison of the findings obtained by variation, grouping and evaluating the common and different findings can be done and the validity and reliability can be ensured. (Cepni, 2010). Variation can be done as sample or data variation (Yildirim and Simsek, 2013). In this study, data variations were made. In order to ensure validity in the study, the validity ways explained briefly below were used. Descriptive validity: It is the type of validity in which it is revealed with all its reality without changing the meaning of the subject being investigated. In this study, while transferring the data obtained from the cases, descriptive validity was tried to be provided by the interpretations after the information about the situation was determined. Interpretive Validity: Relates to the putting forward of meanings, interpretations or purposes derived from the person (s) or situations studied. In this research, by making interviews with prospective teachers explaining their thoughts and opinions was ensured. Theoretical Validity: This is the degree to which the research can explain the subject. Both the researcher and the participants participate in the theoretical constructs. Here, theory is considered as explanation. In this study, while making theoretical configurations, explanations of prospective teachers who are subject to case studies are taken into consideration. Generalization Validity: It's making generalizations in order that the theory made by the research data can ensure the same meaning integrity. Generalization is done within the study group. In this study, it was tried to make generalizing validity by applying analytical generalization, not statistical, since a case study was conducted with 122 prospective teachers. Evaluator Validity: It is the decision of the researcher about the subject and implementing these decisions. In this research, the researcher made evaluations about the situations related to the subject. In order to ensure reliability in the research, the following measures were taken into consideration.1. A detailed description of the situation on the researcher's study, 2. Giving explanatory information about the obtained data, 3. Explanation of all phases of the methods used, 4. Submission of data and analysis to control of the persons participating in the study 5. Submission of data, analyzes and comments to another researcher (Ekiz, 2003). In the study, the above mentioned validity and reliability criteria were taken into consideration. First of all, data diversification has been made so that each data sources can support each other and consistency can be ensured. Finally, all data obtained within the scope of the research were controlled by analysis and taking expert opinion.

\section{Findings}

At the end of the semi-structured interviews, the responses of the prospective teachers to the interview form about the School Experience course and the frequency values of these answers are given in this section.

In the 1st question, the question of "How do you evaluate the removal of the School Experience course in the 2018-2019 academic year in the undergraduate program updated by HEC? Please explain." was handled in the theme 
of "The place of the School Experience course in the program". The answers of the prospective teachers to this question are found in Table 3.

Table 3. Prospective Teachers' Views about the Place of School Experience Course in the Program and Frequencies

\begin{tabular}{|c|c|c|}
\hline Theme & Code & $\mathrm{f}$ \\
\hline \multirow{9}{*}{ 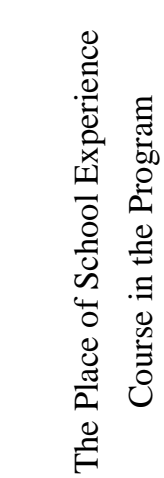 } & The course should not be removed & 57 \\
\hline & A required course in order to gain experience & 39 \\
\hline & A useful course & 13 \\
\hline & Course should be given in the 3 rd year & 7 \\
\hline & As observation is important the course is necessary & 6 \\
\hline & The course is required to observe the school environment & 4 \\
\hline & The removal of the course makes more sense & 4 \\
\hline & Course hours should increase & 3 \\
\hline & Course must be mandatory & 1 \\
\hline
\end{tabular}

Looking at Table 3, there are 9 different views which include the views of prospective teachers on question 1 . The most important issues that prospective teachers emphasized about the place of School Experience course in the program are firstly "The course should not be removed" and secondly "A required course in order to gain experience". In addition to this, 3 prospective teachers said "Course hours should increase", six prospective teachers said "As observation is important the course is necessary", a prospective teacher said "Course must be mandatory", thirteen prospective teachers said "A useful course", seven prospective teachers said "Course should be given in the 3rd year", four prospective teachers said "The course is required to observe the school environment" and four prospective teachers said "The removal of the course makes more sense."

Some of the statements written by the prospective teachers on the interview form regarding the 1st question are as follows.

PT5: "I think the hour of the course should be increased instead of removing the School Experience course. It's also wrong that this course is only in grade 4."

PT31: "Students definitely need the School Experience course. It adds a lot of experience. We got to know the kids by spending time with them."

PT36: "I see this situation as negative. Because the most important thing in the teaching profession is experience. It is a bad situation to make a teaching profession without experience."

PT55: "I think the School Experience course shouldn't be removed. Because I think that prospective teachers should learn how to behave in the school, analyze teacher-student communication and how to lecture and then they should start their career."

PT70: "The removal of the School Experience course negatively affects students' ability to practice, self-develop and explain their deficiencies."

PT77: "I find the School Experience course necessary, but the conditions of the school where we go should be considered."

PT109: "School Experience course is an essential application for prospective teachers. It is an application where prospective teachers are fully active and get information. It's removal is not right for both prospective teachers and students."

In the 2nd question, the question of "According to you, how does the School Experience course reflect the teaching profession? At which level do you think the School Experience course is useful for you? Please explain." was handled in the theme of "The contribution of School Experience course to teaching profession". The answers of the prospective teachers to this question are found in Table 4. 
Table 4. Prospective Teachers' Views about the Contribution of School Experience Course to Teaching Profession and Frequencies

\begin{tabular}{|c|c|c|}
\hline Theme & Code & $\mathrm{f}$ \\
\hline \multirow{11}{*}{ 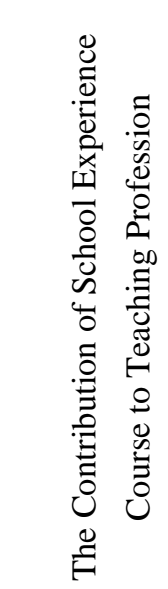 } & Gains experience & 41 \\
\hline & Useful for profession & 38 \\
\hline & Does not reflect the profession & 11 \\
\hline & Gives you the chance to practice & 11 \\
\hline & To love the profession & 7 \\
\hline & Classroom management knowledge & 6 \\
\hline & Inadequate & 6 \\
\hline & Student teacher relationship & 5 \\
\hline & Recognition of the school & 4 \\
\hline & Observing the teacher & 4 \\
\hline & Useful to learn how to use methods and techniques & 1 \\
\hline
\end{tabular}

Looking at Table 4, there are 11 different views which include the views of prospective teachers on question 2. The most important issues that prospective teachers emphasized about the contribution of School Experience course to teaching profession are firstly "Useful for profession" and secondly "Gains experience". In addition to this, six prospective teachers said

"Inadequate" and "Classroom management knowledge", eleven prospective teachers said "Does not reflect the profession" and "Gives you the chance to practice", a prospective teacher said "Useful to learn how to use methods and techniques", five prospective teachers said "Student teacher relationship", seven prospective teachers said "To love the profession", four prospective teachers said "Recognition of the school" and "Observing the teacher". Some of the statements written by the prospective teachers on the interview form regarding the 2nd question are as follows.

PT5: "This course showed me how different the theory and practice were. Just because you know a subject doesn't mean you can follow it. It made me realize that."

PT31: "It made me see class management as practical."

PT36: "It reflects the fact that the teaching profession is intertwined with all the facts. As a teacher, I think you should teach me how to behave and how to think when I encounter negative behaviors. We're gaining experience."

PT55: "It is useful for our professional life. First of all, it is of great benefit to observe the teacher-student relationship and to teach the lesson."

PT70: "I think it is very useful in implementing what we know.

PT77: "We can see what kind of school we will face in the professional sense."

PT109: "It allows us to look at the students from a different perspective at school."

In the 2nd question, the question of "Do you think what will you win thanks to the education you get in the schools you go to within the scope of the School Experience course?" was handled in the theme of "The contribution of the application school to the teaching profession". The answers of the prospective teachers to this question are found in Table 5. 
Table 5. Prospective Teachers' Views about the Contribution of Application School to Teaching Profession and Frequencies

\begin{tabular}{|c|c|c|}
\hline Theme & Code & $\mathrm{f}$ \\
\hline \multirow{7}{*}{ 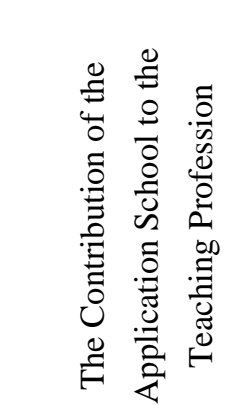 } & Experience & 77 \\
\hline & Classroom management & 14 \\
\hline & To be able to understand students & 14 \\
\hline & To be planned and responsible & 8 \\
\hline & Observing the student & 5 \\
\hline & Course did not contribute & 2 \\
\hline & Learning the profession & 1 \\
\hline
\end{tabular}

Looking at Table 5, there are 7 different views which include the views of prospective teachers on question 3. The most important issue that prospective teachers emphasized about the contribution of application school to teaching profession is "experience". In addition to this, fourteen prospective teachers said "Classroom management" and "To be able to understand students", five prospective teachers said "Observing the student", eight prospective teachers said "To be planned and responsible", two prospective teachers said "Course did not contribute" and a prospective teacher said "Learning the profession". Some of the statements written by the prospective teachers on the interview form regarding the 3 rd question are as follows.

PT5: "I had a lot of opportunities to observe teachers and students in the School Experience course. Every moment we should be prepared for every situation and time and class management should be provided very well."

PT31: "I think I'm not going to have problems when I first meet with children."

PT36: "I think it adds positive behaviors to my professional life. I feel like I'm a teacher in my internship school and this affects my behavior."

PT55: "I think I'll make it easier to communicate with students. I learned how to follow a course when I am teaching."

PT70: "We can consider this course as a step of a profession that we will carry out by practicing. I think it is a lesson that provides a lot of accumulation in terms of teaching profession."

PT77: "The only thing the course got me was to get to know the profession better. Unfortunately, I couldn't benefit from teachers in school."

PT109: "In our profession, I learned how to treat our students and how we should examine them. This was a very nice application for this aspect."

In the 4th question, the question of "Does your experience you gain in the School Experience course contribute to your values education (justice, friendship, honesty, self-control, patience, respect, love, responsibility, patriotism and helpfulness)?" was handled in the theme of "The contribution of School Experience course to values education". The answers of the prospective teachers to this question are found in Table 6.

Table 6. Prospective Teachers' Views about the Contribution of School Experience Course to Values Education and Frequencies

\begin{tabular}{|c|c|c|}
\hline Theme & Code & $\mathrm{f}$ \\
\hline \multirow{8}{*}{ 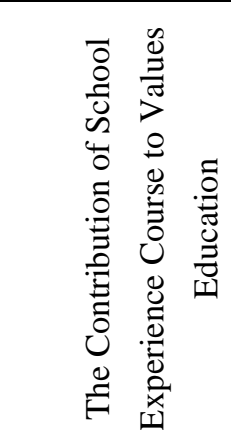 } & Yes, it contributed & 96 \\
\hline & The emotions of patience and love increased & 12 \\
\hline & The sense of responsibility has improved more & 7 \\
\hline & No, it didn't contribute & 6 \\
\hline & Sometimes, it contributed & 4 \\
\hline & The weak aspects were developed & 4 \\
\hline & Motivation increased & 1 \\
\hline & Communication skills developed & 1 \\
\hline
\end{tabular}


Looking at Table 6, there are 8 different views which include the views of prospective teachers on question 4 . The most important issue that prospective teachers emphasized about the contribution of School Experience course to values education is "Yes, it contributed". In addition to this, four prospective teachers said "Sometimes, it contributed" and "The weak aspects were developed", seven prospective teachers said "The sense of responsibility has improved more", twelve prospective teachers said "The emotions of patience and love increased", a prospective teacher said "Motivation increased" and "Communication skills developed". Some of the statements written by the prospective teachers on the interview form regarding the 4th question are as follows.

PT5: "It certainly does. We need to be very patient to the students as well as our responsibilities."

PT31: "It definitely contributes."

PT36: "Its contribution to patience and love is great. We can ignore some disrespectful behaviors of the students with tolerance and patience."

PT55: "It is a very important lesson to contribute my values education very much for my professional life."

PT70: "Of course it does. It contributes to a complete sense of these feelings."

PT77: "I don't think it contributes."

PT109: "Yes, I think it contributes. I learned to treat each student equally."

In the 5th question, the question of "Do you think the application teacher you observed in the School Experience class is a professional teacher model for you?" was handled in the theme of "Application teacher's teaching contribution". The answers of the prospective teachers to this question are found in Table 7.

Table 7. Prospective Teachers' Views about Application Teacher's Teaching Contribution and Frequencies

\begin{tabular}{lll}
\hline Theme & Code & $\mathrm{f}$ \\
\hline & No, he/she didn't contribute & 44 \\
& Yes, he/she contributed & 38 \\
& Partially contributed & 28 \\
& Traditional teacher & 15 \\
& Helped in gaining experience & 9 \\
\hline
\end{tabular}

Looking at Table 7, there are 5 different views which include the views of prospective teachers on question 5. About application teacher's teaching contribution, thirty-eight prospective teachers said "Yes, he/she contributed", fourty-four prospective teachers said "No, he/she didn't contribute", twenty-eight prospective teachers said "Partially contributed", fifteen prospective teachers said "Traditional teacher" and nine prospective teachers said "Helped in gaining experience". Some of the statements written by the prospective teachers on the interview form regarding the 5 th question are as follows.

PT5: "I think about applying some of the behaviors in my professional life but I do not think about applying some behaviors."

PT31: "He helped me gain a lot of experience. "

PT36: "Mostly yes. Because she is a model teacher in the field knowledge and lecture and about the values such as patience, love, justice. However, there is a negative situation because she does not use different methods and techniques.."

PT55: "Yeah, I think. Our teacher's communication with students and teachers, teaching techniques were professional."

PT70: "No, I do not think. Due to the age, the efficiency of the teacher was low and the field knowledge was taught without bringing the technology together."

PT77: "No, I do not think. I wish they were more helpful and guiding. On the contrary, they had different expectations from us."

PT109: "In some ways, yes. The teacher was very moderate, loving and respectful to his students. But there were some shortcomings in his academic knowledge. He was having trouble in providing classroom management." 
In the 6th question, the question of "Do you think the School Experience course improves your professional communication skills? Please explain." was handled in the theme of "The contribution of School Experience course to communication skills." The answers of the prospective teachers to this question are found in Table 8 .

Table 8. Prospective Teachers' Views about the Contribution of School Experience Course to Communication Skills and Frequencies

\begin{tabular}{|c|c|c|}
\hline Theme & Code & $\mathrm{f}$ \\
\hline \multirow{8}{*}{ 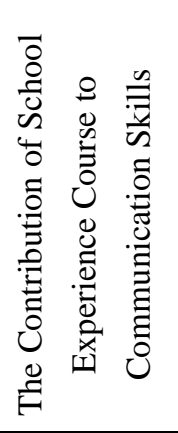 } & Yes, it developed & 88 \\
\hline & I learned how to communicate with children & 36 \\
\hline & I learned how to communicate with teachers & 7 \\
\hline & My self-confidence has increased & 5 \\
\hline & Professional communication skills improved slightly & 3 \\
\hline & To overcome the excitement of giving a lecture & 3 \\
\hline & My classroom management skills developed & 2 \\
\hline & No, it didn't develope & 2 \\
\hline
\end{tabular}

Looking at Table 8, there are 8 different views which include the views of prospective teachers on question 6 . The most important issues that prospective teachers emphasized about the contribution of School Experience course to communication skills are firstly "Yes, it developed" and secondly "I learned how to communicate with children." In addition to this, seven prospective teachers said "I learned how to communicate with teachers", three prospective teachers said "Professional communication skills improved slightly" and "To overcome the excitement of giving a lecture", five prospective teachers said "My self-confidence has increased", two prospective teachers said "My classroom management skills developed" and "No, it didn't develope." Some of the statements written by the prospective teachers on the interview form regarding the 6th question are as follows.

PT5: "I definitely think it's developing. I have experienced that you should try to explain different expressions when your students do not understand the explanations that you think they are explanatory enough."

PT31: "Yes, the longer time we spend with children, the better we can communicate."

PT36: "Yes, it contributed to my skill of thinking and behaving like a teacher."

PT55: "Yeah, I think. I developed professional communication skills through my communication with teachers, students and administration in our school."

PT70: "Yeah, I think. My dialogue with students increased and my perspective developed."

PT77: "I think it is useful for contacting children."

PT109: "I think I have developed my professional communication skills. Because I listened more and tried to understand more. I put myself in the position of the students and tried to behave accordingly."

\section{Conclusion and Discussion}

In the present study, the following results were obtained based on the findings and comments obtained from the interview form used.

When we look at the theme of "The Place of School Experience Course in the Program" the majority of prospective teachers stated that the course should not be removed and it's a required course in order to gain experience. They also stated that the course hours should be increased and it should be given in the earlier classes. In the study of Tural (2018), it was emphasized that the hours of School Experience course should be increased and it would be more beneficial to train teachers to increase their effectiveness by allocating more time to the School Experience course. Alkan, Simsek and Erdem (2013) reported that the prospective teachers were required to spend more time in application schools and it's necessary as they needed to get used to the profession. Allen and Wright (2014), in their study conducted with students in the faculty of education, stated that the school experience course is important because it can be a bridge between theory and practice. In his study which supports these views, Saratli (2007) stated that School Experience course should be given in the first year. It is another view that the course is important to observe the school environment and therefore useful. In addition to these positive opinions, there are also few prospective teachers who indicate that it is more appropriate to remove the course. 
When we look at the theme of the "The contribution of the School Experience course to the teaching profession", most of the prospective teachers stated that the School Experience course is useful to the profession and is a necessary lesson to gain experience. The prospective teachers also mentioned that they have gained important experiences for the teaching profession such as class management knowledge, method and technique usage knowledge, student teacher relationship, chance to practice, school recognition, observing teacher etc. Ceylan and Akkus (2007) support the view that the School Experience course is providing professional competency to prospective teachers. In addition, some prospective teachers said that School Experience did not reflect the teaching profession.

When we look at the "The Contribution of the Application School to the Teaching Profession" theme, most of the prospective teachers stated that the application school is important for gaining experience. Again some of the prospective teachers stated that the application school contributed to the knowledge of classroom management, understanding the students, observing the students and recognizing the profession. A small number of prospective teachers stated that the course did not have any contribution and they didn't get efficiency. Tekin, Bayraktar, Yildiz and Akyuz (2006), similar to this result in their study; stated that prospective teachers did not recognize the teaching profession with different aspects because they made observations in the same schools and classes in the schools in the School Experience course and therefore the course did not contribute.

When we look at the theme of "The contribution of the School Experience course to values education"; prospective teachers stated that this course is an application that contributes to all values and especially the feelings of patience and love towards students. They also said that their weak aspects were developed. Aydın, Selcuk and Yeşilyurt (2007), supported this view stating that in School Experience course prospective teachers perceived themselves as teachers and therefore their thoughts about teaching profession changed in a positive way. There are also prospective teachers who say that the course has no contribution.

When we look at the "Application Teacher's Teaching Contribution" theme it is seen that some of the prospective teachers think that the application teacher has contributed to them and some of them think that the teacher has made no contribution. Teachers who are considered to have contributed to them are good at the classroom management, teach their lessons with different methods and techniques, they are loved and respected by students while the teachers who are considered to have not contributed to them don't improve themselves, do not give up the traditional method, do not use technology, do not interact with the student and aren't good at the classroom management. Cicek and Ince (2005), concluded that the professional experience required for the teaching profession was gained with modelling the application teacher in the School Experience course. Batman (2010), supports this conclusion by stating that the application teachers are insufficient in terms of new curricula, teaching methods and techniques and implementation activities. Mueller and Skamp (2003), in their study with prospective teachers, emphasized that the guidance of teachers in the practice school is very important.

When we look at the theme of "The contribution of the School Experience course to communication skills", prospective teachers reported that communication skills are improved by this course. They stated that they learned communication with students, increased self-confidence and improved classroom management skills. Two prospective teachers stated that their communication skills did not improve.

\section{References}

Akgul, A. (2006). Evaluation of faculty-school cooperation program by music teacher candidates. (Unpublished master's thesis). Obtained from the HEC National Thesis Center database. (Thesis number: 191747).

Alkan, V., Simsek, S. \& Erdem, A. R. (2013). Recommendations of school administrators and instructional staff for School Experience course in application schools . e-Journal of New World Sciences Academy. 8(2), 245-260. Access address: http://nwsa.dergipark.gov.tr/download/article-file/185400

Allen, J. M. \& Wright, S. E. (2014). Integrating theory and practice in the pre-service teacher education practicum. Teachers and Teaching, 20(2), 136-151. https://doi.org/10.1080/13540602.2013.848568

Aydin, S., Selcuk, A.\& Yesilyurt, M.(2007). The views of prospective teachers about the school experience II course. Journal of Yüzüncü Yll University Faculty of Education, 4(2), 75-90. Access address: http://efdergi.yyu.edu.tr/makaleler/cilt_IV/ii/22_a_selcuk.pdf

Aylar, F. \& Aksin, A. (2011). A research on social studies teacher candidates' self-efficacy belief levels and problem solving skills (Amasya Example). Ahi Evran University Kırşehir Education Faculty Journal, 12(3), 299-313 Access address: http://dergipark.gov.tr/download/article-file/15463 
Batman, D. (2010). Determining the effect of school practices on the professional skill development of physicspractice teachers: The case of Trabzon province. . (Unpublished master's thesis). Obtained from the HEC National Thesis Center database. (Thesis number: 259861).

Buyukozturk, S., Cakmak, E. K., Akgun, O, E., Karadeniz, S. \& Demirel, F. (2014). Scientific research methods (18th Edition). Pegem Academy Publishing, ISBN: 9789944919289, Ankara.

Ceylan, T. \& Akkus, Z. (2007). Behavior changes made by school experience II on teacher candidates. Ataturk University Journal of Social Sciences. 9(1), 213-225. Access address: http://e-dergi.atauni.edu.tr/ataunisosbil/article/view/1020000403/1020000396

Cepni, S. (2010). Introduction to research and project studies, (5 th edition), Trabzon.

Cicek, S. \& İnce, L. (2005). Teacher candidates' views on the process of teaching practice, H.U. Journal of Sport Sciences, 16(3), 146-155. Access address: http://www.sbd.hacettepe.edu.tr/fulltext/2005_3_3.pdf

Ekiz, D. (2003). Introduction to research methods and techniques in education: qualitative, quantitative and critical theory methodologies. Ankara: An1 Publishing. ISBN: 9789944474757.

Kahyaoglu, M. \& Yangin, S. (2007). Views of primary school teacher candidates on their professional self-efficacy. Kastamonu Education Journal, 15(9), 73-84. Access address: http://kefdergi.com/pdf/15_1/73.pdf

Katranci, M. (2008). The levels of application school coordinators and application teachers' duties and responsibilities fulfillment: Kırıkkale Province Case. Obtained from the HEC National Thesis Center database.

Kocaturk, F. (2006). The views of the teaching staff, practice teachers and teacher candidates about the school experience II course. Obtained from the HEC National Thesis Center database. (Thesis number: 173494).

Mueller, A. \& Skamp, K. (2003). Teacher candidates talk: listen to the unsteady beat of learning to teach. Journal of Teacher Education, 54(5), 428-440. https://doi.org/10.1177/0022487103256902

Ozdemir, M. (2010). Qualitative data analysis: A study of the methodology problem in the social sciences. Eskişehir Osmangazi University Journal of Social Sciences, 11(1), 323-343. Access address: http://dergipark.gov.tr/download/article-file/113287

Saratli (Unlu), E. (2007). The adequacy of the mentoring service offered to prospective science teachers in the application of School Experience-I course: Siirt Province Case. Obtained from the HEC National Thesis Center database. (Thesis number: 207033).

Saritas, M. (2007). Evaluation of the views on the benefits of the school experience I application to the candidate teachers. Uludag University Faculty of Education Journal, 20(1), 121-143. Access address: http://dergipark.gov.tr/download/article-file/153310

Tekin, M., Bayraktar, G., Yildiz, M. \& Akyuz, A. (2006). İnstitutional methodological and motivational views of physical education and sports school teacher candidates that they have shown towards school experience-I course activity according to various variables. Ataturk University Journal of Physical Education and Sport Sciences, 8(3), 43-54. Access address: http://dergipark.gov.tr/ataunibesyo/issue/28861/308744

Tural, A. (2018). The effect of School Experience Course on Teaching Profession According to Social Studies Teacher Candidates. Obtained from the HEC National Thesis Center database. (Thesis number: 517272).

Yetim, A. \& Goktas, Z. (2004). Professional and Personal Qualifications of Teachers. Kastamonu Education Journal, 12(2), 541-550.

Yildirim, A. and Simsek H. (2013). Qualitative research methods in the social sciences. Ankara: Seçkin Publishing. ISBN: 9789750226038. 